\title{
What it feels like to have a facial disfigurement
}

\author{
Victoria Wright, 38, lives with an unusual facial appearance. She describes her experiences and \\ the lessons she'd like to pass on
}

\section{Victoria Wright}

The first time I realised that I looked different was when a boy called me "fat chin" at primary school. Thirty years later I still remember the burning shame and humiliation.

I was born with cherubism, a rare genetic condition which is associated with variable degrees of abnormal bony overgrowth of the lower part of the face. I started to show signs of this when I was 4.

Before then I looked like every other little girl. But over time my jaw grew bigger, my eyes started to protrude, and the bridge of my nose became flat.

\section{Looking different}

Growing up with such an unusual appearance was not easy. I was stared at and called names by other children, and even adults as well.

Medical journals in the 1980s said cherubism regressed after puberty. I remember telling my mum that I didn't mind looking this way as long as I looked "normal" by the time I started college. Instead my symptoms progressed throughout my teens. The medical literature says cherubism is a painless condition, yet I experienced frequent bouts of pain and discomfort in my sinus and eyes and still do.

Luckily I had a loving and supportive family and once I was diagnosed in the mid 1980s I was followed up by a fantastic NHS maxillofacial department with regular check-ups for my face, teeth, and eyes. When I was 16, the growths were putting pressure behind my eyes (I have proptosis) and NHS surgery saved the sight in my right eye.

Apart from that episode my maxillofacial consultant (now retired), who was warm and friendly, never pressured me to have surgery. He gave me the information that I needed to make my own choices in adulthood

Not all the doctors I have encountered have been as sensitive. I remember telling one that I'd accidentally knocked my eyelid. It had been painful and distressing. "That happens a lot with people whose eyes protrude," he chuckled. This did not help. What I'd needed was sympathy and reassurance as to what to do when it occurred again.
Sometimes I feel it's expected of me to allow medical students to observe because of the rarity of my condition. I don't always mind, but I wish doctors would ask before bringing in their students.

\section{Don't assume surgery is the answer}

When I meet doctors for the first time, some express surprise that I've chosen not to have surgery to reduce the size of my jaw. When I explain that - to paraphrase Henry Higgins in $M y$ Fair Lady_I have become accustomed to my (funny) face, some get it and some don't.

Sometimes I've seen a new doctor about a functional issue or something unrelated to my face, only to be told "we have excellent surgeons here by the way" as their eyes rest on my jaw. I'd prefer to be asked "is there anything else we can do to support you?" That way, I can bring up the topic of surgery myself-if I choose to do so. It can be tiring to explain why I've chosen not to have surgery, especially when that isn't even the reason why I'm there in the first place!

I am not anti-surgery and I know other people with cherubism who have had it and it has been the right choice for them. But my facial disfigurement is entwined with my sense of identity. If I choose to have surgery in the future, and I continue to be followed up in a maxillofacial department, it will be for me, not to meet people's expectations as to how I should look.

Throughout my life I've met people who assume that because of how I look, I must live a depressing, isolated life, but I have a good life. I'm a charity campaigner and public relations professional, and I'm blessed with a young daughter who makes me laugh every day.

When I was growing up and starting out as a young woman, I had fantastic care for the physical side of my disfigurement. But I lacked support for my emotional needs stemming from looking different, and having to cope with staring and cruel remarks, I had to build those tools of resilience myself. I now seek to provide such tools to support others with facial disfigurements. 


\section{What you need to know}

- Avoid using terms such as unsightly, abnormal, and deformity—negative language, even in a medical context, can impact on our self esteem

- When meeting new patients, avoid making assumptions-they might be struggling with their appearance or they might be confident with how they look, but have a functional issue, or they might just be seeing you about their bunions

- Signpost to charities that can provide psychosocial support for people with disfigurements

\section{Education into practice}

- Victoria says that doctors have offered her cosmetic treatment before asking whether she feels it is necessary. How would you approach dealing with differences between doctors' and patients' expectations?

- How might you assess the psychosocial effects of disfiguring conditions?

-Which services or sources of support could you refer patients with disfiguring conditions to?

- On the basis of reading this article, what might you do differently in future?

\section{Useful websites}

- Changing Faces (all conditions): www.changingfaces.org.uk

- Katie Piper Foundation (burns and scars): https://katiepiperfoundation.org.uk/

- Cleft Lip and Palate Association: www.clapa.com/

- The Neuro Foundation (neurofibromatosis): www.nfauk.org/

Competing interests: VW worked at Changing Faces for a year, which she recommends as a resource.
Published by the BMJ Publishing Group Limited. For permission to use (where not already granted under a licence) please go to http://group.bmj.com/group/rights-licensing/ permissions 